\title{
THE IMPACT OF TECHNIQUES AND TRANSLATION IDEOLOGY ON THE CLARITY OF PRAGMATIC MEANINGS TRANSLATION OF THE QUR'ANIC IMPERATIVE VERSES
}

\author{
Mohamad Zaka Al Farisi \\ Universitas Pendidikan Indonesia, Indonesia \\ zaka@upi.edu
}

First received: 26 July 2017

Final proof received: 31 January 2018

\begin{abstract}
One of the stylistic features of the Qur'an is the existence of imperative verses that have certain pragmatic meanings. The feature often makes the Indonesian translation of these verses complex. This is mainly related to the fulfillment of the aspect of clarity in translation. This study aims to reveal the subtle translation of imperative verses of the Qur'an with certain pragmatic meanings. This descriptive-evaluative study used the design of embedded case study because the findings apply only to the imperative verses that serve as the research sample. The sample of the study was chosen purposively from the Qur'anic verses that contain imperative speech. They are imperative verses that have certain pragmatic meanings, such as al-tahdid (threatening), al-ihanah (humiliating), and so forth. The focus of the study is on the subtle translation of imperative verses contained in the translation version by UMT. In general, based on the responses of respondents and the test results, the translations of imperative verses by UMT produce acceptable clarity.
\end{abstract}

Keywords: clarity; imperative; pragmatics; Qur'an; translation

Translation of the Qur'an into various languages of the world is a necessity considering many Muslims from different regions who do not understand the Arabic language. Therefore, the presence of an acceptable translation of the Qur'an, especially in the Indonesian language, is highly anticipated. The acceptance of translation of the Qur'an necessitates the fulfillment of aspects of accuracy, clarity, and naturalness in translation (Larson, 1998). Unfortunately, as stated by Abdelaal and Rashid (2016), many Qur'an translations leave problems of meaninglessness, especially the grammatical meaning caused by differences of source language (SL) and target language (TL). Often the translation error is due to the use of the dominant literal technique.

The domination of the literal technique often results inadequate translations because SL and TL differences do not only occur on language level but also on cultural level. Al Farisi (2010) reveals that Al-Qur'an dan Terjemahnya (lit. "The Qur'an and Its Translation", published by the Ministry of Religious Affairs of Indonesia) used literal technique for more than $60.0 \%$ in handling iltifat verses of the Qur'an. In the context of ArabicEnglish translation, literal technique is the only strategy used by Abdullah Yusuf Ali in translating the verses of iltifat (reference switching) from first personal pronoun to third personal pronoun (AlBadani, Awal, \& Zainudin, 2015). In fact, as Kashgary (2011) asserts, equivalence on the word level is difficult to obtain, especially by using only literal technique. There is no absolute equivalence
(Aldahesh, 2014) because translation often leaves the issue of loss. However, from the point of view of relevance theory, Al Farisi's (2013) study reveals that $93.3 \%$ of the readers of Al-Qur'an dan Terjemahnya do not require complex processing efforts to understand kinayah verses despite the use of literal technique. The use of literal technique without doubt has direct impact on the clarity of translation.

Clarity is one of three aspects of translation acceptance proposed by Larson (1998). It is a very important because it is related to the comprehension of SL information in TL. In many cases, differences between SL and TL makes word-for-word or literal translation does not produce meaningful narratives (Al-Sukhni, Al-Kabi, \& Alsmadi, 2016). Moreover, Qur'anic verses have unique style. The research of Al-Farisi (2015) reveals that the literal tendency in the Al-Qur'an dan Terjemahnya cannot be separated from the ideology of foreignization underlying the translation of iltifat verses. Foreignization is appeared in word-for-word translations where aspects of transparency and fluency are often overlooked (Wang, 2013). The neglect of the transparency and fluency aspects of translation suggests that a translation cannot be accepted. In the translations of imperative verses of the Qur'an, the urgency of clarity cannot be ruled out considering that many imperative verses intersect with Islamic jurisprudences. This study aims to reveal the clarity of the translations of the Qur'anic imperative verses that have certain pragmatic meanings. The translation is the version by UMT. 


\section{Clarity of Translation}

Evaluation of translation acceptance includes some important studies of translation. Some experts (such as Buck, 1992; Fawcett, 2000; House, 1997; Ito, 2004; Maier, 1998; Mateo, Martinez, \& Guijarro, 2016; Nababan, Nuraeni, \& Sumardiono, 2012; Schaffner, 1998; Toury, 1995) suggest various models of translation evaluation. Each model has advantages and disadvantages. According to Larson (1998), an acceptable translation necessitates the fulfillment of accuracy, clarity, and naturalness. Clarity is very crucial because it affects readability of a translated text. Clarity allows interaction between readers and translated text, so that the information contained in the translated text can be well understood. Richards, Plat and Weber (2005) assert that clarity of a discourse, including translation, depends on its easiness to read and comprehend. The degree of clarity of a translation text determines reader understanding. A translated text with high clarity degree helps readers to understand the text easier. Conversely, a translated text with low clarity degree hinders readers to understand the text easily.

\section{Formal Form and Imperative Pragmatic Form in Arabic}

Arabic has two types of speech (kalam), namely kalam khabariy and kalam insya'iy (Al-Hasyimi, 2015). The term kalam khabariy is relatively similar to constative speech initiated by John Langsaw Austin in 1960s (see Al Farisi, 2017). It refers to a speech that has possibility of right or wrong. Like constative speech, kalam khabariy is utterance that describes or reports event, experience, or state in the world. The earth travels around the sun is considered kalam khabariy because it presents the possibility of right or wrong. This is said to be true, if the proposition is in accordance with the reality; and is called wrong, if the proposition does not conform to the existing reality.

The term kalam insya'iy, relatively similar to the performative speech, refers to a speech that has no possibility of right or wrong (see Al Farisi, 2017). Kalam insya'iy does not describe and report event, experience, or situation in the world. Therefore, it has no possibility of right or wrong. The imperative utterance (for example, "Go!"') is kalam insya'iy because it does not present the possibility of right or wrong. The sentence has no possibility to prove its truth. Therefore, it cannot be called the right or wrong speech. The sentence Go cannot be said to fit or not in accordance with reality outside the language because its truth cannot be verified. Clearly, the act of $g o$ has not been realized when the speech is delivered, because if the action go is already realized, surely the speaker will not say go. The same is true for other kalam insya'iys. For example, the interrogative sentence "Has the beggar gone?" also has no possibility of right or wrong. By the sentence, speaker wants to find out whether the beggar has gone or not. If the speaker knows that the beggar has gone, surely he will not ask the question.

Broadly speaking, Arabic classifies kalam (speech) into khabariy and insya'iy. The latest, kalam insya'iy, is divided into insya'iy thalabiy and insya'iy ghair thalabiy. The insya'iy thalabiy is used to ask for something that, according to speaker's beliefs, has not been realized when the claim is made (Al-Hasyimi, 2015; Ibnu Alawiy, 2014). Insya'iy thalabiy includes five speech-forms, namely al-amr (imperative), al-nahy (prohibitative), al-istifham (interrogative), al-tamanniy (optative), and al-nida' (vocative). Meanwhile, insya'iy ghair thalabiy is speech that does not demand something that has not been realized when the speech is put forward. Insya'iy ghair thalabiy includes forms of al-madhu wa al-dzamm (praise and condemnation), al-'uqud (contract), al-qasam (allegations), alta'ajjub (admiration), al-raja' (hope), and so on. Here, the study only focuses on the imperative, which is part of kalam insya'iy ghair thalabiy.

This study discusses the verses of al-amr (imperative) in the Qur'an, which has certain pragmatic meanings. In other words, the formal form of the verses is imperative speech, but presents certain pragmatic meanings. There are some distinctions between imperative in Arabic and Indonesian, and it is difficult to equate the imperative concepts in these two languages. In Arabic, as mentioned earlier, al-amr is categorized into insya'iy thalabiy. Usually the al-amr speech contains demand (thalab) to do action desired by speaker. Indonesian has several terms commonly used to refer to al-amr. The equivalent of al-amr, according to Alisjahbana (1978), Keraf (1980), and Moeliono (1992) is kalimat perintah; Slametmuljana (1959), Poedjawijatna and Zoetmulder (1964), and Ramlan (1987) used the term kalimat suruh; while Verhaar (2008) and Rahardi (2010) used the term imperatif, which in addition to refer to imperative sentences, also refers to the form of verbs used in imperative sentences. Based on verb, imperative formal form can be distinguished over passive and active imperatives. The passive imperative presents a relatively weaker degree of instruction than the active imperative. Active imperatives, transparent or transitive active, can be formed from declarative speech by means of subverting subject in the form of a second person (Verhaar, 2008). To soften imperative speech, an insertion of particle -lah can be one option (Rahardi, 2010). In Arabic, imperative verb is made of al-mudhari' (Giv, 2016); and only covers second person (Al-Khatib, 2012; Al-Quran, 2014).

According to Ghalayaini (2016), imperative is the demand for the realization of an action that has not been realized when the demand is submitted. Imperative is related to the demand (thalab) of an 
act based on the superiority of speaker (see AlHasyimi, 2015; Al-Hindawi, Al-Masu'di \& Mirza, 2014; Al-Jarim \& Amin, 2014). In practice, a speaker may actually have, or simply feels, higher power continuum than the interlocutor. The range of the power continuum, according to Eggins (2004), describes the social relationships between speaker and interlocutor in the form of (non-)equality, which in turn contribute to the realization of an imperative speech.

In practice, imperative speech may not present the meaning of command or order, but may instead present certain pragmatic meanings according to the siyaqu al-kalam (cotext) and qarainu al-ahwal (context). The term cotext refers to the elements that are intralinguistic, while context refers to factors that are extralinguistic, such as speaker, interlocutor, situation of speech, and so on. Context, according to Mey (2008, p. 38), is "the surroundings, in the widest sense, that enable the linguistic expressions of their interaction intelligible". The relevance of a speech is understood in a speech event. A speech, as affirmed by Grundy (2008), is seen as a linguistic premise, while the context of speech is seen as a nonlinguistic premise. In this case, implicature is logical conclusion obtained by reasoning over the premise. The existence of context allows interlocutor to present relevant deductions of understanding. Without knowing the context, interlocutor will not understand the pragmatic meaning of a speech.

A particular context can cause a meaning of an imperative speech to shift from its original meaning (Isaraj, 2015; Uthaimin, $1434 \mathrm{H}$ ). According to AlHasyimi (2015), the shift in meaning of an imperative speech can be understood from al-lafzh (word), al-isyarah (gesture), al-kitabah (message), al-'uqad (plot), and al-hal (context) that exist. Therefore, the formal form of imperative may be different from its pragmatic form. The formal form of imperative typically has structural features of imperative verb (fi'lu al-amr), al-mudhari' verb with lamu al-amr, ismu fi'li al-amr, or mashdar that substitutes for imperative verb. In addition, the realization of imperatives is sometimes also a declarative sentence -khabariyyatan lafzhan wa insyaiyyatan ma'nan (declarative utterance with imperative meaning; see Amin \& Safa, 2015; Giv, 2016; Sultani \& Moqaddasi-niya, 2016). Similarly, the imperative formal form existing in the Qur'an is sometimes not used to express the meaning of thalab (demand) because the existence of certain contexts. However, it is intended to present a variety of pragmatic meanings. Therefore, the urgency of the existence of context is fundamental in interpreting a text (Nurkamto, 2016).

According to Ghalayaini (2016), imperative is a demand for the realization of an action that has not been realized yet when the demand is offered. In Arabic, the realization of imperative can be in the forms of fi'lu al-amr such as خُ (Take!), al-fi'lu almudhari' with lamu al-amr such as صِيُنْفِقْ (Give alms!), ismu fi'li al-amr such as صَه (Shut up!), and mashdar that substitutes for imperative verb such as إحْسَانًا (Do good deed!). All these imperative forms present the meaning of demand (thalab). Yet based on cotext and context, the meaning of demand can shift onto certain pragmatic meaning.

Al-Hashimi (2015) identifies 18 pragmatic meanings of imperative speech: $a l-d u$ 'a (prayer), $a l$ iltimas (requesting), al-irshad (guiding), al-tahdid (threatening), al-ta'jiz. (weakening), al-taswiyyah (equating), al-ibahah (allowing), al-ikram (glorifying), al-ta'dib (educating), al-ihanah (humiliating), al-imtinan (conferring), al-dawam (aligning), al-tamanniy (wondering), al-i'tibar (giving lesson), al-idzn (permitting), al-takwin (making), al-takhyir (choosing), and al-ta'ajjub (showing amazement). As-Suyuthi (1386 H) adds two other pragmatic meanings, namely al-indzar (warning) and al-ihtiqar (underestimating). These pragmatic meanings are not presented in Indonesian (see Rahardi, 2010). Here, the clarity of pragmatic meanings translation of the Qur'anic imperative verses was extracted by the use of comprehension test as suggested by Larson (1998). The study thus employed questionnaire and close procedure test for revealing the translation clarity.

\section{METHOD}

This descriptive study is oriented to translation as a cognitive product. The research design is evaluative with embedded case study design. The sample, according to the research objectives, is chosen purposively based on the criteria of the Qur'anic imperative verses, which have certain pragmatic meanings. As a result, the research sample covered 20 imperative verses, which has certain pragmatic meanings, taken from Al Farisi (2016). The translation units, whether on word level, phrase, clause, or sentence, were examined to determine the tendency of translation ideology: foreignization or domestication. This determination is based on the frequency of use of translation techniques in dealing with micro-translation units. The focus of the study is on the impacts of the translation ideology on the subtle translation of imperative verses contained in Al-Qur'anul Karim Tarjemah Tafsiriyah. The translation of the Qur'an elaborated by Ustadz Muhammad Thalib (hereafter referred to as UMT translation) is based on the consideration that this translation, as the name implies, is a free translation.

The data in this study consists of two categories. First, the data are words, phrases, clauses, or sentences contained in the 20 imperative verses of the Qur'an and its translations. The analysis of this data echoes the use of translation techniques used in translating imperative verses. Second, the data covered the form of perceptions of 
forty respondents of native Indonesian speakers who are actually the students of Department of Arabic Education, Indonesia University of Education. The data from respondents was collected using spatial translation questionnaire. Clarity of translation is related to the perception of respondents that there is a degree of understanding of the information contained in the translation. In addition, the clarity is also measured using a close procedure test involving thirty-five respondents. While initially the respondents consisted of 40 students, five of them did not complete the test properly. The test was meant to find the level of understanding of translations at independent (correct $\geq 50 \%$ ), instructional (correct between $30 \%-49 \%$ ), or frustration (correct $<30 \%$ ) levels.

\section{FINDINGS AND DISCUSSION}

Translation is a process of transferring information from SL into TL. The transfer of information into TL, among others, necessitates fulfillment of clarity aspects so that the information can be understood by target reader. The urgency of clarity in translation is as important as accuracy. This means that translations of imperative verses should not only satisfy the aspects of accuracy, but also meet the aspects of clarity. Therefore, information presented in the translated text can be understood by reader. Aspects of clarity are influenced by translation techniques at micro level. The frequency of use of translation techniques determines the tendency of translation ideology to translate imperative verses that have certain pragmatic meanings. In turn, the tendency of translation ideology has an impact on translation of (non-)imperative verses in the UMT's translation.

\section{Tendency of Translation Ideology}

Table 1 shows eleven translation techniques. In general, UMT used three SL-oriented translation techniques. The three translation techniques are literal technique, borrowing technique, and established equivalent technique. The frequency of the use of SL-oriented translation techniques indicates the tendency of translation ideology, which in turn affects the translation clarity. The use of translation techniques is not simplistic, but varies from a single procedure (using only one translation technique), couplet procedure (using two translation techniques), triplet procedure (using three translation techniques); and quartet procedures (using four translation techniques).

In general, Table 1 shows that the literal technique has been dominantly used to translate imperative verses. The dominance of literal technique shows that the translation text has a strong correspondence relationship with the source text. This means that truth is seen as primary in translation (see Newmark, 1988). As facts of matter, truth, which among other things is the presence of pragmatic meaning in each imperative verse, is conveyed in the translation. Beyond that, the UMT's translation used eight TL-oriented translation techniques that include the use of transposition, reduction, linguistic amplification, amplification, modulation, generalization, particularization, and linguistic compression. The orientation of the use of these translation techniques in turn determines the tendency of translation ideology of UMT.

Table 1. The Tendency of UMT's Translation Ideology

\begin{tabular}{lcc}
\hline Translation Technique & Amount & Explanation \\
\hline SL-Oriented & & $(n=477)$ \\
1. Literal & 152 & \\
2. Borrowing & 31 & \\
3. Established equivalent & 3 & \\
Total & $\mathbf{1 8 6}$ & \\
Percent (\%) & $\mathbf{3 9 . 0 \%}$ & Foreignization \\
& & \\
TL-Oriented & & $(n=477)$ \\
1. Transposition & 78 & \\
2. Reduction & 61 & \\
3. Linguistic amplification & 60 & \\
4. Amplification & 52 & \\
5. Modulation & 30 & \\
6. Generalization & 5 & \\
7. Particularization & 3 & \\
8. Linguistic compression & 2 & \\
Total & $\mathbf{2 9 1}$ & \\
Percent (\%) & $\mathbf{6 1 . 0 \%}$ & Domestication \\
\hline
\end{tabular}

Generally, there are two poles of translation ideology: foreignization and domestication. On the one hand, the trend of foreignization is characterized by the use of SL-oriented translation techniques. This trend manifests in the translation of the presence of elements of language and culture of SL within the TL. On the other hand, the trend of domestication is characterized by the use of TLoriented translation techniques. Domestication manifests in the tendency to adjust the elements of language and culture of SL in TL. In practice, the adjustment of language and cultural elements of SL in TL is done by using amplification, modulation, transposition, reduction, and linguistic amplification techniques. Yaqub (2014) asserts that the Qur'an translator should not only understand Islamic culture in depth, but also understand the history and tradition of Islam. In the UMT's translation, the frequency of SL-oriented translation techniques covers $39.0 \%$ of the text. This number is very low when compared to the frequency of TL-oriented translation techniques, which covers $61.0 \%$. This finding confirms that the UMT's translation has a strong domestication tendency in translating imperative verses. The domestication became the UMT's translation ideology in adapting the elements of language and culture of SL in TL. As a result, the translations of imperative verses in the UMT's translation have a high degree of fluency and transparency. Therefore, translations of 
imperative verses in the translation of UMT can be considered as acceptable, as pointed out by the average of the UMT's translation clarity of the Qur'anic imperative verses in Table 2. This indicates that the translations can be understood by the readers easily.

\section{Clarity of Imperative Verses Translation}

Clarity of translation is related to the absence of SL information in TL. Aspects of clarity include the flow of thought, sentence construction, and other grammatical elements. Related to this, clarity is related to the comprehension of information contained in the translated text. In this case, the degree of clarity is concerned with how hard/easy a reader understands information contained in the translated text. The easier translation is understood by readers, the higher degree of clarity. Responses of respondents are required to reveal the clarity of the translation of imperative verses. Respondents were asked to respond the degree of clarity by giving marks whether a translation is clear, less clear, or not clear. The translations of imperative verses are said to be clear when the flows of thought, sentence construction, and grammatical elements can be understood easily. Next, it is said to be less clear when the translation is understandable, but there is still an incomprehensible grasp of thought, grammatical construction, or grammatical elements. Subsequently, when the flows of thought, sentence construction, and grammatical elements are difficult to understand, the translation is considered not clear. Table 2 illustrates the clarity of UMT's imperative verses translation.

The respondents, as Indonesian native speakers, were asked to respond to the clarity of imperative verses contained in the UMT's translations. According to the respondents, the clarity of the translations is acceptable in general. Interesting findings in this study confirmed that the UMT's translations of imperative verses have high degree of clarity with an average of $87.7 \%$. This number indicates that the translations of imperative verses can be easily understood by reader. In fact, there are translations of imperative verses that have a very high degree of clarity. They are Chapter Yusuf verse 21 (95.6\%), Chapter Yunus verse 80 (94.4\%), Chapter Gafir verse 68 (93.3\%), Chapter Qaf verse 23-24 (92.2\%), Chapter al-Zukhruf verse 77 (91.1\%), Chapter Yunus verse 101 (91.1\%), Chapter al-Isra' verse $48(91.1 \%)$, Chapter alMursalat verses 45-46 (90.0 \%), Chapter alMu'minun verses 107-108 (90.0\%), Chapter Yusuf verse 9 (88.9\%), Chapter Ali 'Imran verse 93 $(87.8 \%)$, Chapter al-Mulk verse $13(85.6 \%)$, and Chapter Ibrahim verse 30 (83.3\%).

In addition to responses from respondents, the translation clarity of the imperative verses was also examined by using close procedure test. The use of close procedure test aims to reveal whether the degree of translation clarity is at the level of independent, instructional, or frustration. The independent level indicates that reader can understand the UMT's translations of imperative verses independently. The instructional level indicates that reader can understand the translations with the help of others. The frustration level indicates that reader has difficulty in understanding the translations.

Table 2 The UMT's Translation Clarity of the Qur'anic Imperative Verses

\begin{tabular}{clc}
\hline No. & Translation & Clarity (\%) \\
\hline 1 & Chapter al-Baqarah: 201 & 82.2 \\
2 & Chapter Luqman: 17 & 81.1 \\
3 & Chapter Ibrahim: 30 & 83.3 \\
4 & Chapter al-Baqarah: 23 & 82.2 \\
5 & Chapter al-Baqarah: 168 & 86.7 \\
6 & Chapter al-Mulk: 13 & 85.6 \\
7 & Chapter al-Hijr: 45-46 & 85.6 \\
8 & Chapter al-Nahl: 114 & 84.4 \\
9 & Chapter al-Mu'minun: 107-108 & 90.0 \\
10 & Chapter al-Fatihah: 6 & 76.7 \\
11 & Chapter Yunus: 101 & 91.1 \\
12 & Chapter al-Isra': 48 & 91.1 \\
13 & Chapter Ghafir: 68 & 93.3 \\
14 & Chapter Yusuf: 9 & 88.9 \\
15 & Chapter al-Zukhruf: 77 & 91.1 \\
16 & Chapter Yusuf: 21 & 95.6 \\
17 & Chapter al-Mursalat: 45-46 & 90.0 \\
18 & Chapter Yunus: 80 & 94.4 \\
19 & Chapter Qaf: 23-24 & 92.2 \\
20 & Chapter Ali 'Imran: 93 & 87.8 \\
& $\quad$ Average & $\mathbf{8 7 . 7}$ \\
\hline
\end{tabular}

The findings show that the UMT's translations of imperative verses contain 3,220 words. Systematically, the translation text is then superimposed on every fifth word. Subsequently, the respondents were asked to fill in every word that was stacked. Table 3 illustrates the results of the close procedure test for the translations of imperative verses.

In this study, the test involves thirty-five respondents from students of Department of Arabic Education, Indonesia University of Education. After reviewing the UMT's translations of imperative verses, respondents were asked to complete portions of the translated texts systematically. The results of the test reveal that $77.8 \%$ of respondents were able to fill the portions of the translations. These results reinforce the findings about the translation of imperative verses based on respondents' perceptions to $87.7 \%$. Based on the test results, it can be concluded that the translation of imperative verses made by UMT is at an independent level, since the number of correct answers reaches more than $50 \%$. As a result, reader can understand the translations of imperative verses independently without help or explanation from others.

In the micro-schema, the clarity of imperative translations is inseparable from translation 
techniques used in dealing with translation units (word, phrase, clause, or sentence).

Tabel 3 Close Procedure Test of Imperative Verses Translations

\begin{tabular}{|c|c|c|c|}
\hline \multirow{2}{*}{ No. } & \multirow{2}{*}{ Respondent } & \multicolumn{2}{|c|}{ UMT's Translation } \\
\hline & & False & True \\
\hline 1. & USH & 10 & 82 \\
\hline 2. & ZA & 25 & 67 \\
\hline 3. & LR & 10 & 82 \\
\hline 4. & Sli & 16 & 76 \\
\hline 5. & ESJ & 9 & 83 \\
\hline 6. & RAR & 13 & 79 \\
\hline 7. & RNF & 9 & 83 \\
\hline 8. & DFO & 28 & 64 \\
\hline 9. & $\mathrm{AM}$ & 25 & 67 \\
\hline 10. & AAS & 30 & 62 \\
\hline 11. & Sfh & 19 & 73 \\
\hline 12. & $\mathrm{RR}$ & 12 & 80 \\
\hline 13. & HL & 20 & 72 \\
\hline 14. & TSP & 26 & 66 \\
\hline 15. & IM & 33 & 59 \\
\hline 16. & NYR & 12 & 80 \\
\hline 17. & $\mathrm{HH}$ & 38 & 54 \\
\hline 18. & $\mathrm{NKh}$ & 20 & 72 \\
\hline 19. & MR & 29 & 63 \\
\hline 20. & TH & 7 & 85 \\
\hline 21. & ALH & 8 & 84 \\
\hline 22. & GKh & 19 & 73 \\
\hline 23. & ESN & 13 & 79 \\
\hline 24. & $\mathrm{RN}$ & 30 & 62 \\
\hline 25. & WSH & 13 & 79 \\
\hline 26. & $\mathrm{RS}$ & 9 & 83 \\
\hline 27. & CS & 31 & 61 \\
\hline 28. & $\mathrm{AFH}$ & 44 & 48 \\
\hline 29. & MIJ & 44 & 48 \\
\hline 30. & GhA & 14 & 78 \\
\hline 31. & IN & 4 & 88 \\
\hline 32. & $\operatorname{TrR}$ & 19 & 73 \\
\hline 33. & DPL & 32 & 60 \\
\hline 34. & Mri & 23 & 69 \\
\hline 35. & IDM & 21 & 71 \\
\hline Tot: & & 715 & 2505 \\
\hline Perc & & $22.2 \%$ & $77.8 \%$ \\
\hline
\end{tabular}

The proper use of translation techniques has an impact on the clarity of translation (Molina \& Albir, 2002). Based on the findings, the use of reduction and amplification techniques is seen to improve the clarity of imperative verse translations. The use of reduction technique is done by dissolving one or more linguistic elements of SL in TL, while in the amplification technique, it is performed by presenting or explicating one or more linguistic elements of SL in TL (see Molina \& Albir, 2002). Grammatical category changes are commonly done because of differences in Arabic and Indonesian structures. Al-Ghazalli (2012) asserts that grammatical inequality often leads to luxury in the translation of Qur'anic verses, plus the fact that the vocabulary of the Qur'an consists of profound meanings. Therefore, the differences between Arabic and Indonesian require adjustment in the translation of imperative verses on level, structure, or category, as shown in the example below.

1. با بنيّ أقم الصلوة وأمر (Chapter Luqman: 17) بالمعروف وانه عن المنكر و اصبر على ما أصابك ....

In the UMT's translation, the verse is translated as follows.

Wahai anakku tersayang, laksanakanlah shalat, dan suruhlah manusia berbuat baik dan cegahlah manusia berbuat dosa. Bersabarlah kamu menghadapi segala cobaan yang menimpa dirimu....

[O my beloved son, perform the prayer, and tell people to do good and prevent people from sinning. You have to be patient with all the trials that befall you ....]

There are some interesting aspects related to the translation of the verse. First, the phrase يني بيّ which has diminutive morphosyntactic element (tashghir), is translated by a couplet procedure that combines literal and amplification techniques. By using the literal technique, the realization of the phrase translation becomes wahai anakku (O my son); and by using the amplification technique, there is the linguistic element tersayang (beloved) in translation as a form of exploration of the diminutive element. This translation is regarded as having an acceptable grasp, because the phrase يا بنيّ (Wahai anakku tersayang, my beloved son) takes place in the background of a dialogue between a father and his beloved son. The existence of the phrase, as stated by some respondents, helps the readers in understanding the pragmatic meaning of the verse. This is in line with the opinion of AlZuhaili $(1418 \mathrm{H})$ who believes that diminutive form of بنيّ is intended to bring the meaning of isyfaq wa tahabbub (affection) contained in the verse.

Secondly, the verse has three imperative verbs (أمر,أقم) and that were translated by couplet procedure combining literal and reduction techniques. By the literal technique, these three verbs are translated into, laksanakanlah (perform), suruhlah (order), and cegahlah (prevent). Meanwhile, by the reduction technique, the deixis element kamu (you) that implicitly presents in these three verbs is wiped out. As a result, the realization of the translation of these three phrases is considered acceptable, because, in Indonesian, subject in imperative verb is commonly wiped out. In addition, the imperative verb اصبر has also been translated by couplet procedure. However, it incorporated borrowing and amplification techniques. The linguistic element of bersabarlah is presented because of the borrowing technique, while the subject element kamu (you) is presented because of the amplification technique. Unfortunately, the subject element kamu in the phrase bersabarlah kamu (be you patient) is seen less acceptable, because the subject element is in the imperative verb and it is commonly wiped out. In addition, the presence of the pronoun you (kamu) in the phrase 
menghadapi segala cobaan yang menimpa dirimu (with all the trials that befall you) is also deemed to indicate the presence of subject element in the translation.

UMT seems to have adjusted their translation by using transposition technique. The transposition technique is used to change grammatical categories, such as adverbs into verbs (see Molina \& Albir, 2002). Based on the findings, transposition technique occurs at the levels of structure and category. The use of transposition technique at the level of structure is understandable considering Arabic and Indonesian have different structures. At the level of category, the use of transposition technique occurs in many pronouns. This is because Arabic has a variety of pronouns. Arabic has 14 pronouns that are classified into aspects of malefemale and numeral. Every verb commonly has a certain pronoun; and each pronoun has different syntactic functions, i.e. nominative, accusative, or dative. It is not surprising that a sentence in Arabic often contains many pronouns with various syntactic functions. The existence of pronouns in Arabic that is usually anaphoric often confuses reader after the pronouns have been translated literally into Indonesian.

The pragmatic meaning of an imperative verse can be accepted also because the transposition technique used in translating existing pronominal elements, as shown in the following example.

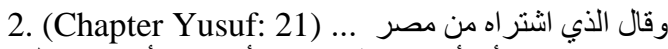
لامر أته أكرمي مثو اه عسى أن ينفعنا أو نتخذه ولدا

In the UMT's translation, the verse is translated as follows.

Seseorang dari Mesir yang membeli Yusuf berkata kepada istrinya: Muliakanlah kedudukan anak ini. Semoga dia kelak memberi manfaat kepada kita atau kita jadikan saja dia anak angkat.

[One from Egypt who bought Joseph said to his wife: Glorify this child's position. Hopefully he will benefit us or we just make him a foster child.]

According to Al-Hasyimi (2015), the verse has the pragmatic meaning of al-takhyir (choosing) which is marked by the existence of the mean word أو أو أو The translated into atau (or) by using literal technique. It makes the clarity of the pragmatic meaning al-takhyir to be relatively acceptable. In Table 1, it appears that the translation of this imperative verse is seen as the most acceptable $(95.6 \%)$. The high degree of clarity of this verse's translation is also reinforced by transposition technique. The realization of the transposition technique is seen in the shift of the pronoun $\bullet$ in the phrase اشتراه (bought him), which is translated into membeli Yusuf (bought Joseph). The shift of the pronoun $\bullet$ in its translation into word Yusuf is to help readers to understand the translation of the verse. It is because the pronoun -nya (him) is anaphoric. It refers to the tarnished Yusuf (Joseph) in Chapter Yusuf verse 20. If the pronoun o was translated by using the literal technique, the translation would become membelinya. Therefore, the phrase اشتراه contained in the verse is translated into membelinya (bought him). In this case, the use of literal technique may cause the translation to be unacceptable, since readers may be confused in determining the antecedents to which the reference of the pronoun -nya (him) in the preceding verse.

The same happened to the clause أكرمي مثواه, which is translated into muliakanlah kedudukan anak ini (glorify this child's position). This translation is accepted because it is readily understood by readers. Based on the verb category, the imperative formal form in this clause is an imperative transitive-active. In UMT's translation the imperative verb أكرمي is translated by couplet procedure combining literal and reduction techniques. By the literal technique, the verb أكرمي is translated into muliakanlah (glorify), and by the reduction technique, the phrase olehmu (by you) implicitly contained in the verb أكرمي that should be the subject for the verb is wiped out. It makes the translation more natural. The translation of the phrase مثو اه into kedudukan anak itu also involved couplet procedure that combines literal and transposition techniques. By the literal technique, the noun 1 is translated into kedudukan (position), while the pronoun $\bullet$ in the phrase oو is translated into anak ini (this child) as the effect of the transposition technique. In these cases, the use of literal technique is inevitable, and it is unavoidable because the use of literal technique implies a corresponding relationship between the translation text and the source text. However, the occurrence of adjustments, either in the form of deletion, addition, or shifting, in the translation is often inevitable when the use of literal technique only presents a translation that is not or less clear. Therefore, in practice, the use of translation techniques is not simplistic. It must be varied according to the need to present a clear translation. Adjustments are made so that the translations of imperative verses become acceptable.

Based on the research findings, transposition technique is also used to shift category from imperative to declarative speech. It can be seen in the following example.

3. (Chapter al-Mulk: 13) وأسروا قولكم أو اجهروا به بهابه إنه عليم بذات الصدور

In the UMT's translation, the verse is translated as follow.

Wahai kaum mukmin, kalian boleh melirihkan atau mengeraskan dzikir kalian. Allah Maha Mengetahui semua isi hati kalian.

[O mankind, you may cast or harden your dhikr. 


\section{Allah knows all what is in your heart.]}

Based on the research findings, as shown in Table 2, the translation of the verse is considered clear. According to Al-Hasyimi (2015), the verse has a pragmatic meaning al-taswiyah (equating). This pragmatic meaning is translated by using transposition technique as shown in the translation of the fragment وأسروا قولكم أو اجرووا به, which is translated to Wahai kaum mukmin, kalian boleh melirihkan atau mengeraskan dzikir kalian (O mankind, you may cast or harden your dhikr). By using transposition technique, this verse undergoes category shifting from imperative to declarative speech. Literally, this verse fragment means and keep your sayings secret or declare them. A category shift is required as an effort to engage in pragmatic adaptation so that the pragmatic meaning desired in the paragraph can be addressed in TL (Volkova \& Zubenina, 2015). This pragmatic adaptation, according to the respondents, is seen to present the pragmatic meaning of equating. The presence of the pronoun kalian (you) by using amplification technique is also seen to make this translation clearer. Unfortunately, according to the respondents, some linguistic elements interfere the translation as a whole. First, the linguistic element wahai kaum mukmin (O believers) is not actually contained in the SL. An additional linguistic element, which is in fact the realization of the linguistic amplification technique is seen to narrow the meaning of this imperative verse, as if this verse was directed only to the believers. Second, the phrase قولكم is translated into dzikir kalian (your dhikr), whereas this phrase literally means your word. The linguistic element of dzikir kalian by using particularisation technique is also considered to narrow the meaning contained in the next fragment, Allah Maha Mengetahui semua isi hati kalian (Allah knows all what is in your heart). This seems to mean that God only reckons dhikr as the only content of human's heart. The fact, Allah knows everything about human, not just the dhikr.

In addition to the transposition technique, the use of linguistic amplification technique made a translation clear. It can be seen in the translation below.

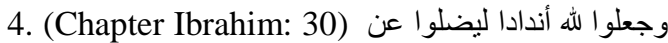

$$
\begin{aligned}
& \text { سبيله قل تمتعو ا فإن مصيركم إلى النار }
\end{aligned}
$$

The imperative verse, according to Al-Zuhaili $(1418 \mathrm{H})$, has the pragmatic meaning al-tahdid (threatening). According to Al-Hasyimi (2015), the presence of this pragmatic meaning can be understood from the plot (al-'uqad) of utterance. The verse contains the first clause that seems ordering, but the second clause is a threat. The UMT translated the verse as follows.

Orang-orang kafir itu telah menjadikan tuhan-tuhan lain sebagai sekutu bagi Allah untuk menyesatkan manusia dari ajaran tauhid. Katakanlah: "Bersenang-senanglah kalian untuk sementara waktu. Tempat kembali kalian kelak adalah neraka."

[The disbelievers have made other gods as allies for Allah to lead people astray from the teachings of monotheism. Say: "You have fun for a while. Your return spot will be hell.”]

The imperative verb تمتعو in this verse is translated into bersenang-senanglah kalian untuk sementara waktu (You have fun for a while). In this case, UMT used triplet procedure that combines three translation techniques: literal, amplification, and linguistic amplification. By using the literal techniques, the imperative verb تمتعو is literally translated into bersenang-senanglah (have fun). Unfortunately, the subject element (kalian [you]), which implicitly exists in the Arabic imperative verb, is made explicit in Indonesian by using the amplification technique. The presence of the subject element in Indonesian imperative sentence is considered unacceptable. Moreover, the linguistic element also appears again in the continuation of the verse. As for the linguistic amplification technique, an additional linguistic element (untuk sementara waktu [for a while]), which is not actually contained in the SL, is deliberately presented in the translation. The presence of this additional linguistic element seems to clarify the pragmatic meaning al-tahdid (threatening). Therefore, as shown in Table 2, the translation of the verse is acceptable $(83.3 \%)$.

In the case of the imperative verse in Chapter al-Baqarah verse 201, which has the pragmatic meaning al-dua' (praying), the use of particularization technique is seen to bring the pragmatic meaning clearer.

$$
\begin{aligned}
& \text { 5. (Chapter al-Baqarah: 201) ومنهم من يقول ربنا } \\
& \text { آتنا في الدنيا حسنة وفي الآخرة حسنة وقنا عذاب النار }
\end{aligned}
$$

The imperative verse, according to Al-Hasyimi (2015), has a pragmatic meaning al-dua' (praying). In UMT's translation, this verse is translated as follows.

Orang yang wuquf di 'Arafah ada juga yang berdo'a: "Wahai Tuhan kami, berilah kami kebaikan di dunia dan kebaikan di akhirat, serta selamatkanlah kami dari siksa api neraka."

[The one who performs wuqup in "Arafah is also the one praying: "O our Lord, grant us the good in the world and the good in the Hereafter, and save us from the torment of hellfire."]

The historical context of this verse, as can be seen in the previous verse (Chapter al-Baqarah: 200), is related to the implementation of the pilgrimage in Mecca. Therefore, the phrase sit.: among them) in this verse is translated by using the transposition technique into Orang yang wuquf di 
'Arafah (the one who wuquf in 'Arafah). Wuquf in 'Arafah is one of the series of pilgrimage ritual. Some respondents said that the translation is very precise because it is in accordance with the historical context of the verse. However, some other respondents argue that the phrase sisould be translated literally, so that the sense of praying in the verse is not only bound in the context of hajj pilgrimage. In spite of these different opinions, the pragmatic meaning al-dua' is presented thoroughly in the translation because of the existence of the linguistic element berdo' $a$, which is the translation of the verb يقول. This is in line with the opinion of Al-Hasyimi (2015) which states that sometimes the pragmatic meaning of an imperative verse can be understood from the presence of certain word (allafzhu). Consequently, respondents' perceptions on the clarity of this verse reached $82.2 \%$. Literally, the verb يقول contained in the verse means to say. However, by using particularization, the verb is translated into berdoa (to pray). The use of this technique can present the pragmatic meaning clearer. The next phrase آتنا in the verse is translated to berilah kami (grant us). The imperative verb آت in this phrase are translated by using couplet procedure that combines two translation techniques: literal and amplification. By using literal technique, the imperative verb آت is translated into berilah (grant), and by using amplification technique, the subject element (oleh-Mu [by you]) is diluted to make this translation more natural. In addition, the insertion of the particle -lah is seen to soften the requestive sentence. Some respondents argued that it would be more appropriate if this translation added politeness marker mohon (beg) because, as Rahardi (2010) states, requestive sentence is usually marked with the politeness marker mohon. If so, the translation of the phrase آتنا in this imperative verse can be translated to mohon berilah kami (begging You, please grant us).

Overall, the whole translation of the Qur'anic imperative verses in the UMT's translation can be said to have reached the acceptable degree of clarity because of the use of proper translation techniques in handling the micro-unit of translation. The abundance of the use of TL-oriented translation techniques presents the high translation clarity. According to the respondents, the clarity of the translations of the Qur'anic imperative verses is so acceptable that the readers can understand them easily. This finding is strengthened by the degree of translation clarity based on the result of respondents' perception that attains the average of $87.7 \%$ and the result of the close procedure test that attains the average of $77.8 \%$. The result of the close procedure test implies that the translations of imperative verses made by UMT reach an independent level, i.e., the readers can understand the translations without any explanation from others. Table 2 shows that Chapter Yusuf verse 21 is the highest degree of translation clarity (95.6\%), while Chapter al-Fatihah verse 6 is the lowest one (76.7\%).

\section{CONCLUSION}

The clarity of translations of Qur'anic imperative verses is influenced by the selection of translation techniques used when dealing with micro-translation units, whether on the levels of word, phrase, clause, or sentence. Although the UMT's translation has a tendency of domestication, the use of literal technique is widely used in the imperative verses translations. In practice, the realization of the literal technique is not only in a single procedure, but also combined with other techniques such as transposition, modulation, amplification, reduction, as well as by couplet, triplet, or quartet procedures.

The UMT translated the Qur'anic imperative verses using a strategy that emphasizes the TL than the SL. It is characterized by the use of TL-oriented translation techniques. The use of this strategy makes the translations of imperative verses is relatively clearer and more transparent. The clarity of imperative verses translation is presented by using some TL-oriented translation techniques such as amplification, transposition, particularization, modulation, linguistic amplification, and reduction. As a result, in general, the translations of imperative verses have acceptable clarity. Overall, the pragmatic meanings stated by Al-Hashimi (2015) is found in the UMT's translation in different degrees. The highest degree of translation clarity is found in the translation of Chapter Yusuf verse 21, while the lowest one is found in the translation of Chapter alFatihah verse 6 . This acceptance is reinforced by the results of the respondents' views and the close procedure test as well, which reveals that the UMT's translation of imperative verses is at an independent level.

\section{REFERENCES}

Al-Badani, N. A., Awal, N. M., \& Zainudin, I. S. (2015). The transfer of the implicature of Iltifat from Arabic into English. Pertanika Journal Social Science \& Humanities, 23, 27-41.

Abdelaal, N. M., \& Rashid, S. Md. (2016). Grammar-related semantic losess in the translation of the Holy Quran, with special reference to Surah Al A'raf (The Heights). Sage Open, 1-11.

Aldahesh, A. Y. (2014). (Un)translatability of the Quran: A theoretical perspective. International Journal of Linguistics, 6(6), 23-44.

Al Farisi, M. Z. (2010). Keterjemahan ungkapan kinayah dalam Bahasa Arab ke dalam Bahasa Indonesia. Bahasa \& Sastra, 10(2), 188-200.

Al Farisi, M. Z. (2013). Aspek relevansi dalam terjemahan tindak tutur kinayah Al-Qur'an. 
KARSA: Jurnal Sosial \& Budaya Keislaman, 2(21), 156-169.

Al Farisi, M. Z. (2015). Speech act of iltifat and its Indonesian translation problems. Indonesian Journal of Applied Linguistics (IJAL), 4(2), 214-225.

Al Farisi, M. Z. (2016). Analisis terjemahan ayatayat imperatif Al-Qur'an (Telaah Komparatif Terjemah DEPAG dan Terjemah UMT) (Unpublished doctoral dissertation). Universitas Pendidikan Indonesia, Bandung.

Al Farisi, M. Z. (2017). Ketedasan terjemahan ayatayat imperatif bernuansa budaya. El Harakah: Jurnal Budaya Islam, 19(2), 159-176.

Al-Ghazalli, M. F. (2012). A study of the English translations of the Qur'anic verb phrase: The derivatives of the triliteral. Theory and Practice in Language Studies, 2, 605-612.

Al-Hasyimi, A. (2015). Jawahiru al-Balaghati fi alMa'ani wa al-Bayani wa al-Badi'. Beirut: Daru al-Kutubi al-'Ilmiyyah.

Al-Hindawi, F. H., Al-Masu'di H. H., \& Mirza, R. F. (2014). The speech act theory in English and Arabic. Open Journal of Modern Linguistics, 4, 27-37.

Al-Jarim, 'A., \& Amin, M. (2014). Al-Balaghatu alWadhihah. Kairo: Daru al-Ma'arif.

Al-Khatib, M. A. (2012). Politeness in the Holy Quran: A sociolinguistic and pragmatic perspective. Intercultural Pragmatics, 9(4), 479-509.

Alisjahbana, S. T. (1978). Tatabahasa baru Bahasa Indonesia. Jakarta: Penerbit Dian Rakyat.

Al-Quran, M. (2014). Inflectional deviation of number in the Qur'an. International Journal of Languages and Literatures, 2(2), 165-186.

Al-Sukhni, E., Al-Kabi, M. N., \& Alsmadi, I. M. (2016). An automatic evaluation for online machine translation: Holy Quran case study. International Journal of Advanced Computer Science and Applications, 7(6), 118-123.

As-Suyuthi, J. (1386 H). Al-Itqanu fi 'Ulumi alQur'an. Kairo: Daru al-Syuruq.

Al-Zuhaili, W. (1418 H). Al-Tafsiru al-Muniru fi al'Aqidati wa al-Syari'ati wa al-Manhaj. Damaskus: Daru al-Fikri al-Muashir.

Amin, N., \& Safa, N. H. A. (2015). Pragmatics analysis: Arabic directive imperative speech acts used in Al-Qur'an. International Journal of Science and Research, 952-955.

Buck, G. (1992). Translation as a language testing procedure: Does it work? Language Testing, 9(2), 123-148.

Eggins, S. (2004). An introduction to Systemic Functional Linguistics ( $2^{\text {nd }}$ ed.). London: Continuum.

Fawcett, P. (2000). Translation in the broadsheets. The Translator, 6(2), 295-307.
Ghalayaini, M. (2016). Jami'u al-Durusi al'Arabiyyah. Beirut: Muassasatu al-Risalati Nasyirun.

Giv, A. L. (2016). Exchange of linguistic forms: Imperative forms indicating interrogation and declarative statement: The instances in Quran. Mediterranean Journal of Social Sciences, 7(3), 456-464.

Grundy, P. (2008). Doing pragmatics ( ${ }^{\text {rd }}$ ed.). London: Hodder Education.

House, J. (1997). Translation quality assessment: Linguistic description versus social evaluation. Meta, 46(2), 243-257.

Ibnu Alawiy, U. (2014). Al-Balaghah: al-Ma'ani, al-Bayan, al-Badi'. Beirut: Daru al-Manhaj.

Isaraj, M. (2015). The value of social context in the use of imperative in English and Albanian languages. International Journal of Recent Scientific Research, 6(9), 6004-6008.

Ito, A. (2004). Two types of translation tests: Their reliability and validity. System, 32(3), 395-405.

Kashgary, A. D. (2011). The paradox of translating the untranslatable: Equivalence vs. nonequivalence in translating from Arabic into English. Journal of King University Language and Translation, 23, 47-57.

Keraf, G. (1980). Tata Bahasa Indonesia untuk Sekolah Lanjutan Atas. Ende: Nusa Indah.

Larson, M. L. (1998). Meaning-based translation: A guide to cross-language equivalence ( $2^{\text {nd }}$ ed.). Boston: University Press of America.

Maier, C. (1998). Reviewing and criticism. In M. Baker (Ed.), Routledge Encyclopedia of Translation Studies, 205-210. London: Routledge.

Mateo, R. M., Martinez, S. M., \& Guijarro, A. J. M. (2016). The modular assessment pack: A new approach to translation quality assessment at the Directorate General for Translation. Perspectives Studies in Translatology, 1-31.

Mey, J. (2008). Pragmatics: An introduction. Cambridge: Blackwell Publisher.

Moeliono, A. M. (1992). Tata Bahasa baku Bahasa Indonesia. Jakarta: Perum Balai Pustaka.

Molina, L., \& Albir, A. H. (2002). Translation techniques revisited: A dynamic and functionalist approach. Meta, 47(4), 498-512.

Nababan, M., Nuraeni, A., \& Sumardiono. (2012). Pengembangan model penilaian kualitas terjemahan. Kajian Linguistik dan Sastra, 24(1), 39-57.

Newmark, P. (1988). Approaches to translation. Oxford: Pergamon Press.

Nurkamto, J. (2016). Pragmatic study of directive speech acts in Stories in Al-Qur'an. Advances in Language and Literary Studies, 7(5), 78-84.

Poedjawijatna, I. R., \& Zoetmulder, P. J. (1964). Tatabahasa Indonesia untuk Sekolah Landjutan Atas. Jakarta: N.V. Obor. 
Rahardi, K. (2010). Pragmatik kesantunan imperatif Bahasa Indonesia. Jakarta: Erlangga.

Ramlan, M. (1987). Ilmu Bahasa Indonesia, Sintaksis. Yogyakarta: CV Karyono.

Richards, J., Plat, J., \& Weber, H. (2005). Longman Dictionary of Applied Linguistics. Harlow: Longman.

Schaffner, C. (Ed.). (1998). Translation and quality. Clevedon: Multilingual Matters.

Slametmuljana. (1959). Kaidah Bahasa Indonesia II. Ende: Penerbit Nusa Indah.

Sultani, S. A. A., \& Moqaddasi-niya. (2016). A study of perlocutionary in two different types of commandments in Quran and their translation. Qur'an-Hadith Translation Studies, 3(6), 191-211.

Toury, G. (1995). Descriptive translation studies and beyond. Amsterdam: John Benjamins.

Uthaimin, M. S. (1434 H). Syarhu al-Balaghati min Kitabi Qawa'idi al-Lughati al- 'Arabiyyah.
Riyadh: Muassasatu al-Syaikhi Muhammad ibn Salih al-'Utsaimin al-Khairiyyah.

Verhaar, J. W. M. (2008). Asas-asas linguistik umum. Yogyakarta: Gadjah Mada University Press.

Volkova, T., \& Zubenina, M. (2015). Pragmatic and sociocultural adaptation in translation: Discourse and communication approach. SKASE Journal of Translation and Interpretation, 8(1), 89-106.

Yaqub, M. (2014). Text-Types, translation types and translation assessment: A case study of Chapter 112 of the Holy Qur'an in Rodwell, AL-Hilali and Khan's translation. International Journal of Humanities and Social Science, 4(8), 225-230.

Wang, L. (2013). A survei on domestication and foreignization theories in translation. Theory and Practice in Language Studies, 3(1), 175179. 